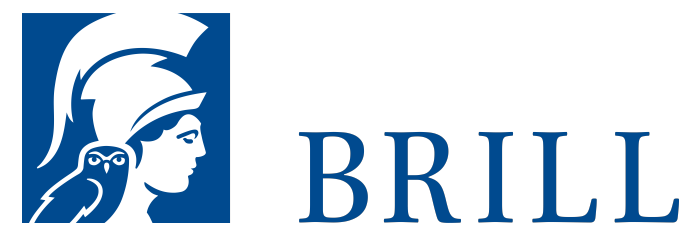

\title{
Omissions and their moral relevance
}

Assessing causal and moral responsibility for the things we fail to do

\section{Author: Pascale Willemsen}

This book empirically investigates the social practice of ascribing moral responsibility to others for the things they failed to do, and it discusses the philosophical relevance of this practice. In our everyday life, we often blame others for things they failed to do. For instance, we might blame our neighbour for not watering our plants during our vacation. Interestingly, the attribution of blame is typically accompanied by the attribution of causal responsibility. We do not only blame our neighbour for not watering our plants, but we do so because we believe that not watering the plants caused them to dry up and die. In this book, I investigate how we make moral and causal judgments about omissions. I discuss different philosophical perspectives on this matter, and I outline to what extent the actual social practice is in line with philosophical theories.

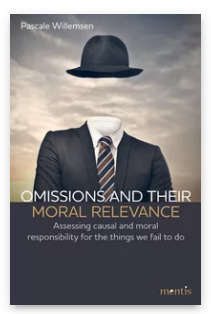

Published: 10

May 2019

Pages: 183

Seiten, $34 \mathrm{~s} / \mathrm{w}$

Graf., 8 s/w Tab.

Subjects: Ethics

\& Moral

Philosophy,

Philosophy

Publisher: Brill | mentis

E-Book (PDF)

ISBN: $978-3^{-}$

95743-795-2

Price:

Paperback

ISBN: 978-3-

95743-152-3

Price: 
Pascale Willemsen is Assistant Professor in philosophy at RuhrUniversity Bochum. Her research focuses on questions related to moral philosophy, moral and causal cognition, the folk concept of lying, and philosophy of mind and action.

Please send your order to: Brockhaus/Commission Tel: +49(o)71 541327 9216 | E-Mail: brill@ $\underline{\text { brocom.de }}$

For questions please contact: Brill Deutschland GmbH Wollmarktstraße 115 | 33098 Paderborn | Germany

Tel: +49 (o)5251 69975 o | E-Mail: sales@brill.com. 